\title{
Simvastatin combined with nifedipine enhances endothelial cell protection by inhibiting ROS generation and activating Akt phosphorylation
}

\author{
Xiao-niao $\mathrm{CHEN}^{1}$, Jun $\mathrm{XU}^{2}$, Zhe FENG ${ }^{3}$, Ming FAN ${ }^{4}$, Jing-yao $\mathrm{HAN}^{1}$, Zhuo YANG ${ }^{1, *}$ \\ ${ }^{1}$ College of Medicine, Nankai University, Tianjin 300071, China; ${ }^{2}$ Beijing ZhongGuanCun Middle School, Beijing 100089, China; \\ ${ }^{3}$ Chinese PLA General Hospital, Beijing 100853, China; ${ }^{4}$ The Academy of Military Medical Sciences, Beijing 100850, China
}

Aim: To investigate the protective effects of simvastatin (Sim) combined with nifedipine (Nif) on endothelial cells and elucidate the action mechanism.

Methods: Human umbilical vein endothelial cells (HUVEC) were used. mRNA and protein levels were measured by using reversetranscription polymerase chain reaction (RT-PCR) and Western blotting, respectively. Intracellular calcium and reactive oxygen species (ROS) were detected using confocal microscopy. The Griess assay was used to evaluate nitric oxide (NO) release.

Results: Treatment of HUVEC with $\mathrm{H}_{2} \mathrm{O}_{2} 100 \mu \mathrm{mol} / \mathrm{L}$ for 30 min inhibited the mRNA and protein expression of endothelial nitric oxide synthase (eNOS). With increased concentrations of Nif, eNOS mRNA and protein levels increased $(P<0.05)$. Combined treatment with Sim $1.0 \mu \mathrm{mol} / \mathrm{L}$ and Nif $1.0 \mu \mathrm{mol} / \mathrm{L}$ significantly increased the mRNA and protein expression of eNOS and NO release compared with $\mathrm{Sim}$ or Nif alone $(P<0.05)$. The combination significantly lowered the intracellular ROS level $(P<0.05)$, which was correlated with the increase in eNOS and NO, but there was no visible change in intracellular calcium $(P>0.05)$. Compared with individual drug treatment, Akt phosphorylation and the ratio of p-eNOS/eNOS were up-regulated in the combination group, and this effect was inhibited by the phosphatidylinositol 3-kinase (PI3K) inhibitors wortmannin and LY294002.

Conclusion: The Sim-Nif combination effectively protects HUVEC against $\mathrm{H}_{2} \mathrm{O}_{2}$ injury by inhibiting intracellular ROS generation, increasing the ratio of $\mathrm{p}$-eNOS/eNOS and up-regulating Akt phosphorylation.

Keywords: vascular endothelial cells; nifedipine; simvastatin; endothelial nitric oxide synthase; nitric oxide; reactive oxygen species; calcium; phosphatidylinositol 3-kinase

Acta Pharmacologica Sinica (2010) 31: 813-820; doi: 10.1038/aps.2010.58; published online 21 June 2010

\section{Introduction}

Hypertension and arteriosclerosis are common maladies among aged people in China and remain the most important risk factors for cardiovascular disease. Aging hypertensive patients often co-present with arteriosclerosis ${ }^{[1]}$. Functional impairment of vascular endothelial cells is involved in the formation of hypertension and arteriosclerosis ${ }^{[2]}$. Therefore, maintenance of vascular endothelial function is important to prevent hypertension and arteriosclerosis ${ }^{[3,4]}$.

Endothelial nitric oxide synthase (eNOS) and the nitric oxide (NO) excreted by eNOS are important regulatory factors of endothelial cells because they protect against the development of hypertension and arteriosclerosis by expanding the blood vessels, inhibiting platelet coagulation and preventing

\footnotetext{
* To whom correspondence should be addressed.

E-mail zhuoyang@nankai.edu.cn

Received 2010-02-28 Accepted 2010-04-21
}

conglutination between blood cells and between blood cells and endothelial cells ${ }^{[5,6]}$. A variety of anti-hypertension drugs have also shown anti-arteriosclerosis activities, independent of blood pressure control ${ }^{[7]}$. Both clinical ${ }^{[8]}$ and experimental ${ }^{[9]}$ studies have indicated that drugs commonly used to control blood pressure, such as nifedipine (Nif), protect the blood vessel wall, inhibit the progress of arteriosclerosis via exerting anti-oxidation and anti-inflammation functions. Statins, another class of drugs used in blood lipid regulation, enhance the expression of eNOS $^{[10]}$ and reduce reactive oxygen species (ROS) damage $\mathrm{e}^{[11]}$. Elderly people with hypertension invariably present with arteriosclerosis. There have been no studies on whether a drug combination therapy can better protect endothelial cells against damage than individual drugs or on the specific mechanisms of such a combination therapy. Here, we used human umbilical vein endothelial cells (HUVEC) to explore the effect and the mechanism of action of combined simvastatin (Sim) and Nif treatment in endothelial cells. 


\section{Materials and methods Reagents and drugs}

Nifedipine and simvastatin were purchased from Sigma (St Louis, MO, USA). Prior to use, $4.2 \mathrm{mg}$ Sim was dissolved in $0.1 \mathrm{~mL}$ of $95 \%$ ethanol and then added to $0.15 \mathrm{~mL}$ of $0.1 \mathrm{~mol} / \mathrm{L}$ $\mathrm{NaOH}$, followed by incubation in a water bath for $2 \mathrm{~h}$ at $50{ }^{\circ} \mathrm{C}$ (this opened the closed lactone ring to activate it). Sim was brought to $\mathrm{pH} 7.2$ with $\mathrm{HCl}$ and added to $1 \mathrm{~mL}$ deionized water, yielding a Sim concentration of $1 \mathrm{~mol} / \mathrm{L}$. It was kept at $-20{ }^{\circ} \mathrm{C}$ until use ${ }^{[12,13]}$. The phosphatidylinositol 3-kinase (PI3K) inhibitors wortmannin and LY294002 were purchased from Sigma. The calcium probe Fluo-3/AM, intensifier Pluronic F-127, intracellular ROS probe CM- $\mathrm{H}_{2}$ DCFDA, fetal calf serum (FCS) and Dulbecco's modified Eagle's medium (DMEM) were purchased from Invitrogen (Eugene, OR, USA). $\mathrm{H}_{2} \mathrm{O}_{2}$ (AR Grade) was from Taopu Chemical Plant (Shanghai). Dilutions were made prior to use and were used within $5 \mathrm{~min}$. The dilutions were kept out of direct light. The reagent box for the Griess assay was purchased from Beijing Kanghuiyu Technology Co, Ltd. Rabbit polyclonal anti-human eNOS, phosphorylated eNOS (Ser1177), Akt, p-Akt and $\beta$-actin antibodies and goat anti-rabbit IgG antibody were purchased from Santa Cruz Biotechnology Inc (Santa Cruz, CA, USA). Hanks' Buffered Saline solution (HBSS) (Sigma, St Louis, MO, USA ) was used for normal cell buffer liquid.

\section{Cell culture for HUVEC}

HUVEC from ATCC (Manassas, VA, USA) were grown in DMEM with $10 \%$ FCS in $25-\mathrm{cm}^{2}$ culture flasks at $37{ }^{\circ} \mathrm{C}$ and $5 \%$ $\mathrm{CO}_{2}$. Media were changed every 2-3 days.

\section{Experimental groups}

HUVEC were divided into seven groups:

Control

$100 \mu \mathrm{mol} / \mathrm{L} \mathrm{H}_{2} \mathrm{O}_{2}\left(100 \mu \mathrm{mol} / \mathrm{L} \mathrm{H}_{2} \mathrm{O}_{2}\right.$ cell incubation for 30 $\min$ )

$100 \mu \mathrm{mol} / \mathrm{L} \mathrm{H}_{2} \mathrm{O}_{2}+0.1 \mu \mathrm{mol} / \mathrm{L}$ Nif $\left(100 \mu \mathrm{mol} / \mathrm{L} \mathrm{H}_{2} \mathrm{O}_{2}+0.1\right.$ $\mu \mathrm{mol} / \mathrm{L}$ Nif, cell incubation for $30 \mathrm{~min}$ )

$100 \mu \mathrm{mol} / \mathrm{L} \mathrm{H}_{2} \mathrm{O}_{2}+1.0 \mu \mathrm{mol} / \mathrm{L}$ Nif $\left(100 \mu \mathrm{mol} / \mathrm{L} \mathrm{H}_{2} \mathrm{O}_{2}+1.0\right.$ $\mu \mathrm{mol} / \mathrm{L}$ Nif, cell incubation for $30 \mathrm{~min}$ )

$100 \mu \mathrm{mol} / \mathrm{L} \mathrm{H}_{2} \mathrm{O}_{2}+10 \mu \mathrm{mol} / \mathrm{L} \mathrm{Nif}\left(100 \mu \mathrm{mol} / \mathrm{L} \mathrm{H}_{2} \mathrm{O}_{2}+10\right.$ $\mu \mathrm{mol} / \mathrm{L} \mathrm{Nif}$, cell incubation for $30 \mathrm{~min}$ )

$100 \mu \mathrm{mol} / \mathrm{L} \mathrm{H}_{2} \mathrm{O}_{2}+1.0 \mu \mathrm{mol} / \mathrm{L} \operatorname{Sim}(1.0 \mu \mathrm{mol} / \mathrm{L}$ Sim, cell incubation for $2 \mathrm{~h}$; $100 \mu \mathrm{mol} / \mathrm{L} \mathrm{H}_{2} \mathrm{O}_{2}$, cell incubation for $30 \mathrm{~min}$ )

$100 \mu \mathrm{mol} / \mathrm{L} \mathrm{H}_{2} \mathrm{O}_{2}+1.0 \mu \mathrm{mol} / \mathrm{L} \mathrm{Nif}+1.0 \mu \mathrm{mol} / \mathrm{L} \operatorname{Sim}(1.0$ $\mu \mathrm{mol} / \mathrm{L}$ Sim, cell incubation for $2 \mathrm{~h} ; 100 \mu \mathrm{mol} / \mathrm{L} \mathrm{H}_{2} \mathrm{O}_{2}$ and 1.0 $\mu \mathrm{mol} / \mathrm{L}$ Nif, cell incubation for $30 \mathrm{~min}$ )

mRNA analysis by reverse transcriptase polymerase chain reaction (RT-PCR)

eNOS mRNA expression was detected by RT-PCR. HUVEC were split into 6-well plates, serum-starved for $12 \mathrm{~h}$ and stimulated as detailed above. After rinsing with HBSS, total RNA was extracted with Trizol according to the manufacturer's instructions (Invitrogen). cDNAs were made from $1.0 \mu \mathrm{g}$ of total RNAs with the RT-PCR Reagent kit (Promega,
Madison, WI, USA) following the manufacturer's instructions. Semiquantitative PCR was carried out with the PTC200 PCR thermocycler (MJ Research, Waltham,MA, USA). The genes encoding human eNOS and GAPDH (normalization control) were examined. The eNOS primer sequences were based on the human eNOS full-length cDNA sequence provided by GenBank and were designed with Prime5.0 software. The forward primer was 5'-AAG ATC TCC GCC TCG CTC A-3'; the reverse primer was 5'-GCT GTT GAA GCG GAT CTT A-3'. The eNOS amplicon length was $336 \mathrm{bp}$. The PCR mix contained cDNA $1.0 \mu \mathrm{L}, 25 \mathrm{mmol} / \mathrm{L} \mathrm{MgCl}_{2} 5.0 \mu \mathrm{L}$, dNTP $1 \mu \mathrm{L}$, forward primer $0.25 \mu \mathrm{L}$, reverse primer $0.25 \mu \mathrm{L}, 10 \times \mathrm{PCR}$ reaction buffer $2.5 \mu \mathrm{L}$, and Taq DNA polymerase $0.5 \mu \mathrm{L}$. Deionized water was added to a final volume of $25 \mu \mathrm{L}$. The PCR program was $94{ }^{\circ} \mathrm{C}$ for $5 \mathrm{~min}, 35$ cycles of $94{ }^{\circ} \mathrm{C}$ for $45 \mathrm{~s}, 56^{\circ} \mathrm{C}$ for $45 \mathrm{~s}$ and $72{ }^{\circ} \mathrm{C}$ for $45 \mathrm{~s}$, followed by extension at $72{ }^{\circ} \mathrm{C}$ for $7 \mathrm{~min}$. The forward GAPDH primer was 5'-GAA TTT GGC TAC AGC AAC AGG GT G-3'; the reverse primer was 5'-TCT CTT CCT CTT GTG CTC TTG CTG-3'. The amplicon length was $204 \mathrm{bp}$. The PCR mix contained cDNA $1.0 \mu \mathrm{L}, 25 \mathrm{mmol} / \mathrm{L}$ $\mathrm{MgCl}_{2} 2.0 \mu \mathrm{L}$, dNTP $1.0 \mu \mathrm{L}$, forward primer $0.5 \mu \mathrm{L}$, reverse primer $0.5 \mu \mathrm{L}, 10 \times \mathrm{PCR}$ buffer $2.5 \mu \mathrm{L}$, Taq polymerase 0.25 $\mu \mathrm{L}$, and deionized water to a final volume of $25 \mu \mathrm{L}$. The PCR program was $94{ }^{\circ} \mathrm{C}$ for $5 \mathrm{~min}, 35$ cycles of $94{ }^{\circ} \mathrm{C}$ for $45 \mathrm{~s}, 58^{\circ} \mathrm{C}$ for $45 \mathrm{~s}$ and $72{ }^{\circ} \mathrm{C}$ for $45 \mathrm{~s}$, followed by extension at $72{ }^{\circ} \mathrm{C}$ for $7 \mathrm{~min}$.

The expanded products were photographed after electrophoresis in $1.5 \%$ agarose. The grayscale of all bands was analyzed under a gel imaging system (ALPHA IMAGER2200).

\section{Western blot analysis}

HUVEC were grown to reach about $80 \%$ confluence, followed by serum-starving synchronization for $12 \mathrm{~h}$ and then applying the treatments. Each well was rinsed two times in HBSS, and total protein was extracted with $200 \mu \mathrm{L}$ RIPA lysis solution (0.5 mmol/L Tris pH 7.4, $1.5 \mathrm{mmol} / \mathrm{L} \mathrm{NaCl}, 10 \% \mathrm{~Np}-40,10$ $\mathrm{mmol} / \mathrm{L}$ EDTA, $100 \mu \mathrm{g} / \mathrm{mL}$ PMSF), $2 \mu \mathrm{g} / \mathrm{mL}$ aprotinin, and $2 \mu \mathrm{g} / \mathrm{mL}$ leupeptin. A BCA protein reagent kit (Pierce, US) was used to measure protein concentration. Electrophoresis was carried out by loading $100 \mu \mathrm{g}$ total protein in $10 \%$ polyacrylamide gels. Proteins were transferred to cellulose acetate membranes, blocked with $10 \%$ non-fat milk, and detected with 1:200 eNOS, 1:200 Akt, 1:200 p-Akt and 1:200 $\beta$-actin antibodies overnight at $4{ }^{\circ} \mathrm{C}$. Anti-IgG secondary antibody (1:2000) conjugated to horseradish peroxidase was then added at room temperature for $1 \mathrm{~h}$. After washing in TBST, the membrane was labeled with ECL reagents, and grayscale analysis was conducted using an image analysis system (Alphaimager 2200; Alpha Innotech Corp, San Leandro, CA, USA). The level of protein expression was analyzed by normalizing to $\beta$-actin.

\section{Fluorescence measurement of intracellular calcium changes}

The cultured HUVEC were cultured in 35-mm culture chambers designed for confocal microscopy (MatTek Corp, US). The cultured endothelial cells were synchronized with nonserum media for $12 \mathrm{~h}$. After cells reached the dish walls, they 
were rinsed two times with $37^{\circ} \mathrm{C}$ HBSS and incubated for 15 min at $37^{\circ} \mathrm{C}$ in $7.5 \mu \mathrm{mol} / \mathrm{L}$ Fluo-3 and $0.02 \%$ Pluronic F-127 diluted in HBSS containing $\mathrm{Ca}^{2+}$ and $\mathrm{Mg}^{2+}$. Cells were rinsed with HBSS three times, placed in a dark room for $10 \mathrm{~min}$, and observed under the $60 \times$ oil-immersion objective of a Radiance 2000 laser scanning confocal microscope (LSCM) (Zeiss). The 49-mW argon ion laser was used, with an excitation wavelength of $488 \mathrm{~nm}$. The fluorescent image of each layer of Fluo3 -stained cells was observed and collected. The scanning employed a time-course procedure with an interval of $5 \mathrm{~min}$ for collection of dynamic scanning data for seven cycles (ie, continuous detection for $30 \mathrm{~min}$ ). The dynamic fluorescent image observed by high-speed computer was drawn in curved lines of fluorescence intensity changes of $\mathrm{Ca}^{2+}$. Lasersharp 2000 software (version 6.0) attached to the LSCM was used to analyze the data. At least 40 cells were selected for each experiment. The $\mathrm{Ca}^{2+}$ concentration in each cell was represented by mean fluorescence intensity (in arbitrary units).

Fluorescence measurement of intracellular reactive oxygen species (ROS)

The membrane-permeable CM- $\mathrm{H}_{2}$ DCFDA entered endothelial cells and produced a fluorescent signal after intracellular oxidation by ROS, such as hydrogen peroxide and hydroxyl radical. Intracellular oxidant stress was monitored by measuring changes in fluorescence resulting from intracellular probe oxidation $^{[14,15]}$. The cultured HUVEC were plated in the 35-mm confocal microscopy culture dishes and synchronized with non-serum media for $12 \mathrm{~h}$. After cells reached the dish walls, they were rinsed two times with $37^{\circ} \mathrm{C}$ HBSS. CM- $\mathrm{H}_{2} \mathrm{D}$ CFDA diluted in HBSS to a final concentration of $5.0 \mu \mathrm{mol} /$ $\mathrm{L}$ was added to the cells, which were incubated at $37^{\circ} \mathrm{C}$ for 30 min. After three HBSS washes, cells were placed in a dark room for $10 \mathrm{~min}$ and observed by LSCM. Using the $49-\mathrm{mW}$ argon ion laser, the excitation wavelength was $488 \mathrm{~nm}$, and the emission wavelength was 505-530 nm. The intracellular ROS changes were observed in a dynamic state under the $60 \times$ oil-immersion lens (in a dark room). The scanning employed a time-course procedure with a 5-min interval for collection of dynamic scanning data and nine data collection points (ie, continuous detection for $40 \mathrm{~min}$ ). The dynamic fluorescence image was analyzed as above. At least 35 cells were selected for each experimental group.

\section{Measurement of NO levels}

NO secreted from cells is rapidly oxidized to nitrite in culture medium; therefore, determination of nitrite concentrations was used as a measurement of NO production. A colorimetric Griess assay (Jiancheng Ins, Nanjing, China) was used. Briefly, HUVEC were cultured at $1 \times 10^{6} / \mathrm{mL}$ in a 24 -well plate, $1 \mathrm{~mL} /$ well, at $37^{\circ} \mathrm{C}$ and $5 \% \mathrm{CO}_{2}$. The cells had grown to the wall after $24 \mathrm{~h}$. The clear supernatant medium was removed and replaced with $1 \mathrm{~mL}$ fresh culture medium. The cells were divided according to the aforementioned experimental groups and collected $4 \mathrm{~h}$ after drug treatment. Following the manufacturer's instructions, the clear supernatant medium was col- lected to detect the NO level by the Griess method.

\section{Statistical analysis}

All data are presented as mean \pm SEM. Statistical significance was assessed using the Student's paired $t$-test and variance. All data analyses were performed using the software SPSS 10.0. $P<0.05$ was considered statistically significant.

\section{Results}

Simvastatin combined with nifedipine enhances the eNOS mRNA expression in endothelial cells

Stimulation with $100 \mu \mathrm{mol} / \mathrm{L} \mathrm{H}_{2} \mathrm{O}_{2}$ for $30 \mathrm{~min}$ decreased eNOS mRNA expression remarkably compared with the control group. The eNOS mRNA expression was enhanced significantly after Nif was added ( $P<0.05$ vs $\mathrm{H}_{2} \mathrm{O}_{2}$ group), and this effect was dose-dependent $\left(P<0.05\right.$ vs $100 \mu \mathrm{mol} / \mathrm{L} \mathrm{H}_{2} \mathrm{O}_{2}+0.1$ $\mu \mathrm{mol} / \mathrm{L}$ Nif group, Figure 1).
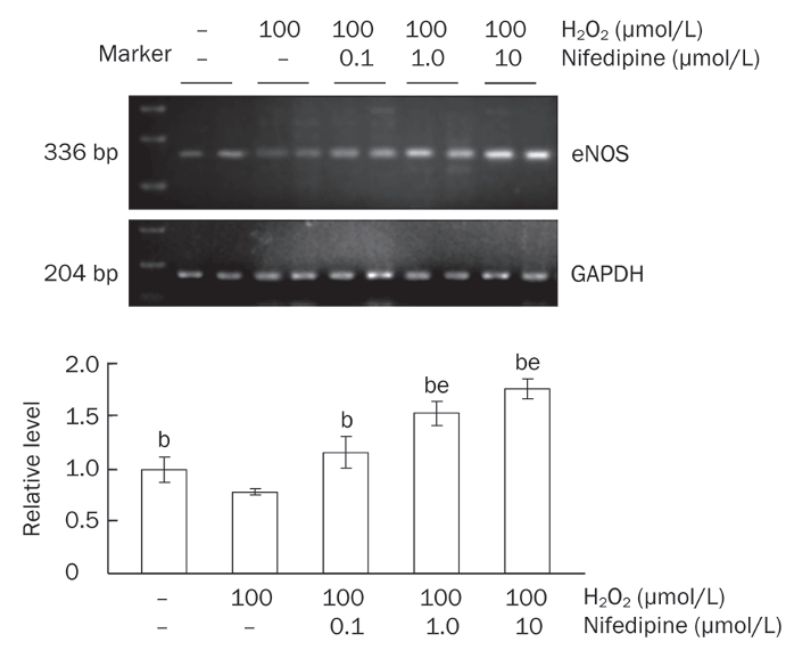

Figure 1. The concentration-dependent effect of nifedipine on eNOS mRNA expression in endothelial cells after hydrogen peroxide-induced injury. Optical densities were obtained after normalization to GAPDH. Data are presented as mean \pm SEM from three independent experiments. ${ }^{\mathrm{b}} \mathrm{P}<0.05$ vs $\mathrm{H}_{2} \mathrm{O}_{2}$ group. ${ }^{\mathrm{e}} \mathrm{P}<0.05$ vs $100 \mu \mathrm{mol} / \mathrm{L} \mathrm{H}_{2} \mathrm{O}_{2}+0.1 \mu \mathrm{mol} / \mathrm{L}$ nifedipine group.

The eNOS mRNA expression increased significantly after $1.0 \mu \mathrm{mol} / \mathrm{L} \mathrm{Nif}+1.0 \mu \mathrm{mol} / \mathrm{L}$ Sim stimulation compared with adding $1.0 \mu \mathrm{mol} / \mathrm{L}$ Nif or $1.0 \mu \mathrm{mol} / \mathrm{L}$ Sim alone, reaching 1.8fold higher than that from Nif alone $\left(P<0.05\right.$ vs $\mathrm{H}_{2} \mathrm{O}_{2}$ group, vs $100 \mu \mathrm{mol} / \mathrm{L} \mathrm{H}_{2} \mathrm{O}_{2}+1.0 \mu \mathrm{mol} / \mathrm{L}$ Sim group and vs $100 \mu \mathrm{mol} / \mathrm{L}$ $\mathrm{H}_{2} \mathrm{O}_{2} 1.0 \mu \mathrm{mol} / \mathrm{L}$ Nif group). These results indicate that Nif protected endothelial cells from $\mathrm{H}_{2} \mathrm{O}_{2}$ damage and enhanced the expression of eNOS mRNA. This effect was enhanced significantly when Sim was added, indicating increased protection of endothelial cells (Figure 2).

Simvastatin combined with nifedipine enhances the expression of eNOS protein in endothelial cells

The eNOS protein in HUVEC decreased significantly after 30 

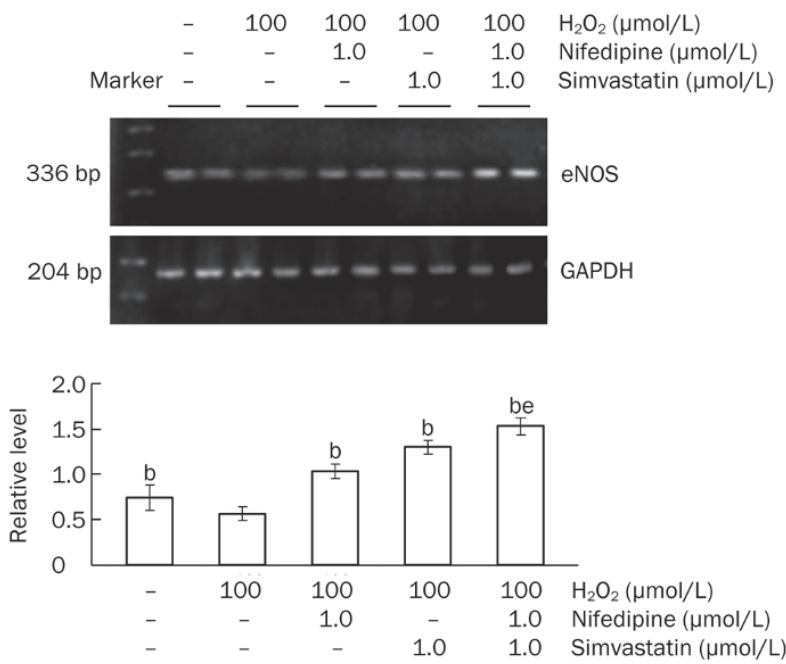

Figure 2. The concentration-dependent effect of simvastatin combined with nifedipine on eNOS mRNA expression in endothelial cells after hydrogen peroxide-induced injury. Optical densities were obtained after normalization to GAPDH. Data are presented as mean \pm SEM from three independent experiments. ${ }^{\mathrm{b}} \mathrm{P}<0.05$ vs $\mathrm{H}_{2} \mathrm{O}_{2}$ group. ${ }^{\mathrm{e}} \mathrm{P}<0.05$ vs 100 $\mu \mathrm{mol} / \mathrm{L} \mathrm{H}_{2} \mathrm{O}_{2}+1.0 \mu \mathrm{mol} / \mathrm{L}$ simvastatin group or $100 \mu \mathrm{mol} / \mathrm{L} \mathrm{H}_{2} \mathrm{O}_{2}+1.0$ $\mu \mathrm{mol} / \mathrm{L}$ nifedipine group.

min of stimulation with $100 \mu \mathrm{mol} / \mathrm{L} \mathrm{H}_{2} \mathrm{O}_{2}$, and the expression of eNOS protein was enhanced dose dependently by Nif ( $P<0.05$ vs $\mathrm{H}_{2} \mathrm{O}_{2}$ group; $P<0.05 ; 100 \mu \mathrm{mol} / \mathrm{L}_{2} \mathrm{O}_{2}+0.1 \mu \mathrm{mol} / \mathrm{L}$ Nif group vs $100 \mu \mathrm{mol} / \mathrm{L} \mathrm{H}_{2} \mathrm{O}_{2}+10 \mu \mathrm{mol} / \mathrm{L}$ Nif group, Figure 3). We also found that the increased expression of eNOS protein was enhanced significantly by the combination of Sim and Nif compared with Sim or Nif alone $\left(P<0.05\right.$ vs $\mathrm{H}_{2} \mathrm{O}_{2}$ group; $P<0.05$ vs $100 \mu \mathrm{mol} / \mathrm{L} \mathrm{H}_{2} \mathrm{O}_{2}+1.0 \mu \mathrm{mol} / \mathrm{L}$ Sim group and vs 100 $\mu \mathrm{mol} / \mathrm{L} \mathrm{H}_{2} \mathrm{O}_{2}+1.0 \mu \mathrm{mol} / \mathrm{L}$ Nif group) (Figure 4). These results indicate that the expression of eNOS protein increased more by joint application of Sim and Nif than by application of Sim
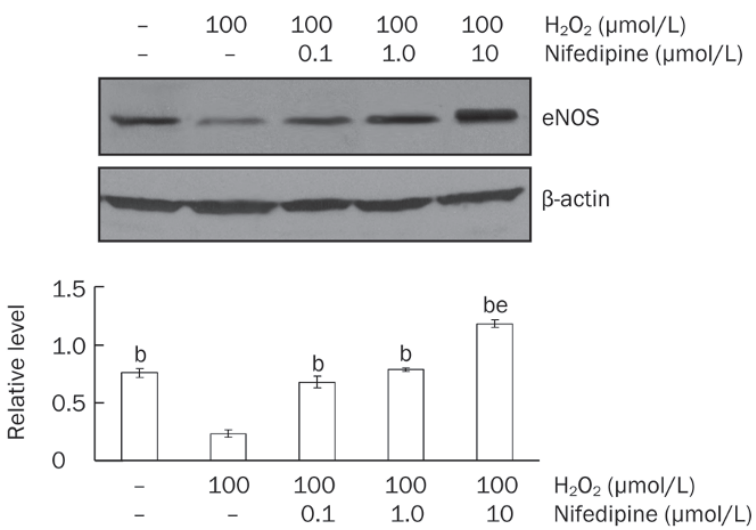

Figure 3. The concentration-dependent effect of nifedipine on eNOS protein expressions in endothelial cells after hydrogen peroxide-induced injury. Optical densities were obtained after normalization to $\beta$-actin. Data are presented as mean \pm SEM from three independent experiments. ${ }^{\mathrm{b}} \mathrm{P}<0.05$ vs $\mathrm{H}_{2} \mathrm{O}_{2}$ group. ${ }^{\mathrm{e}} \mathrm{P}<0.05$ vs $100 \mu \mathrm{mol} / \mathrm{L} \mathrm{H}_{2} \mathrm{O}_{2}+0.1 \mu \mathrm{mol} / \mathrm{L}$ nifedipine group or $100 \mu \mathrm{mol} / \mathrm{L} \mathrm{H}_{2} \mathrm{O}_{2}+1.0 \mu \mathrm{mol} / \mathrm{L}$ nifedipine group.
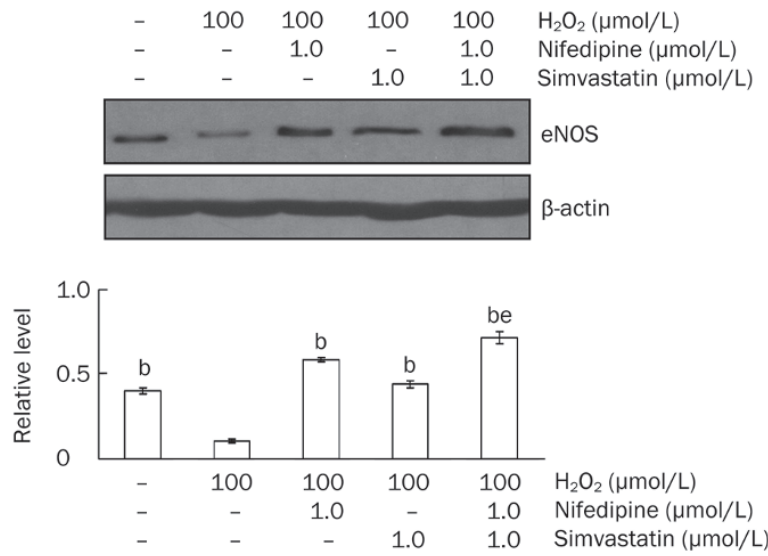

Figure 4. Effect of simvastatin combined with nifedipine on endothelial eNOS protein expression in endothelial cells after hydrogen peroxideinduced injury. Optical densities were obtained after normalization to $\beta$-actin. Data are presented as mean \pm SEM from three independent experiments. ${ }^{b} P<0.05$ vs $\mathrm{H}_{2} \mathrm{O}_{2}$ group. ${ }^{\mathrm{e}} \mathrm{P}<0.05$ vs $100 \mu \mathrm{mol} / \mathrm{L} \mathrm{H}_{2} \mathrm{O}_{2}+1.0$ $\mu \mathrm{mol} / \mathrm{L}$ simvastatin group or $100 \mu \mathrm{mol} / \mathrm{L} \mathrm{H}_{2} \mathrm{O}_{2}+1.0 \mu \mathrm{mol} / \mathrm{L}$ nifedipine group.

or Nif alone, thereby enhancing the protective action of these drugs for endothelial cells.

Simvastatin combined with nifedipine enhances NO secretion more than individual treatments in endothelial cells

The above results showed that Nif and Sim enhanced the expression of eNOS protein and mRNA. However, the increased eNOS does not automatically imply a protective effect of these two drugs for the cells. Therefore, further investigation was carried out by using the Griess assay to examine NO secretion in the cells upon different drug treatments. Table 1 shows that $\mathrm{NO}$ generation decreased markedly in the cells treated with $100 \mu \mathrm{mol} / \mathrm{L} \mathrm{H}_{2} \mathrm{O}_{2}$ compared with no treatment $(69.43 \pm 6.80 \mu \mathrm{mol} / \mathrm{L}$ vs $40.22 \pm 6.70 \mu \mathrm{mol} / \mathrm{L}, P<0.01, n=6)$. NO secretion increased to $60.80 \pm 6.67 \mu \mathrm{mol} / \mathrm{L}$ or $52.74 \pm 5.40$ $\mu \mathrm{mol} / \mathrm{L}$, respectively, after adding $1.0 \mu \mathrm{mol} / \mathrm{L}$ Nif or 1.0 $\mu \mathrm{mol} / \mathrm{L} \operatorname{Sim}(P<0.01, n=6)$. Upon combined drug treatment, the secretion of $\mathrm{NO}$ increased to $82.68 \pm 6.51 \mu \mathrm{mol} / \mathrm{L}(P<0.01$ vs $1.0 \mu \mathrm{mol} / \mathrm{L}$ Nif and $v s 1.0 \mu \mathrm{mol} / \mathrm{L}$ Sim separately, $n=6)$. These results indicate that joint drug treatment increased NO secre-

Table 1. The endothelial $\mathrm{NO}$ generation in different groups. ${ }^{\circ} P<0.01$ vs control. ${ }^{\mathrm{f}} P<0.01$ vs $100 \mu \mathrm{mol} / \mathrm{L} \mathrm{H}_{2} \mathrm{O}_{2}+1.0 \mu \mathrm{mol} / \mathrm{L}$ nifedipine group or 100 $\mu \mathrm{mol} / \mathrm{L} \mathrm{H}_{2} \mathrm{O}_{2}+1.0 \mu \mathrm{mol} / \mathrm{L}$ simvastatin group.

Group (n=6)

Endothelial NO product $(\mu \mathrm{mol} / \mathrm{L})$

Control

$100 \mu \mathrm{mol} / \mathrm{L} \mathrm{H}_{2} \mathrm{O}_{2}$

$100 \mu \mathrm{mol} / \mathrm{L} \mathrm{H}_{2} \mathrm{O}_{2}+1.0 \mu \mathrm{mol} / \mathrm{L}$ Nifedipine $100 \mu \mathrm{mol} / \mathrm{L} \mathrm{H}_{2} \mathrm{O}_{2}+1.0 \mu \mathrm{mol} / \mathrm{L}$ Simvastatin $100 \mu \mathrm{mol} / \mathrm{L} \mathrm{H}_{2} \mathrm{O}_{2}+1.0 \mu \mathrm{mol} / \mathrm{L}$ Nifedipine $+1.0 \mu \mathrm{mol} / \mathrm{L}$ Simvastatin
$69.43 \pm 6.80$

$40.22 \pm 6.70^{\circ}$

$60.80 \pm 6.67$

$52.74 \pm 5.40$

$82.68 \pm 6.51^{\text {cf }}$ 
tion in endothelial cells compared with Sim or Nif treatment separately, thereby providing better protection for endothelial cells against oxidative damage.

Stronger inhibitory effect on ROS generation from joint Sim and Nif treatment compared with separate treatments

The above results show that the expression of eNOS mRNA and protein was reduced by $100 \mu \mathrm{mol} / \mathrm{L} \mathrm{H}_{2} \mathrm{O}_{2}$ in endothelial cells and that Nif and Sim inhibited this damaging effect. It has been reported ${ }^{[7,8]}$ that calcium channel blockers and statins affect eNOS expression via many pathways, such as ROS signaling, calcium signaling and the bradykinin pathway.

To investigate the mechanism of protection provided by Sim and Nif, intracellular ROS were marked with the specific fluorescent probe CM- $\mathrm{H}_{2}$ DCFDA in HUVEC, and we carried out dynamic real-time detection by LSCM. The fluorescence intensity of CM-CDFDA increased remarkably from stimulation with $100 \mu \mathrm{mol} / \mathrm{L} \mathrm{H}_{2} \mathrm{O}_{2}$, reaching a peak after $30 \mathrm{~min}$, which meant that $\mathrm{H}_{2} \mathrm{O}_{2}$ stimulation was able to increase ROS in cells. Moreover, ROS generation was inhibited by Nif in a dose-dependent manner ( $P<0.05$ vs B group, $n=35-45$ cells) (Figure 5). However, adding $1.0 \mu \mathrm{mol} / \mathrm{L}$ Sim along with 1.0 $\mu \mathrm{mol} / \mathrm{L}$ Nif significantly reduced the fluorescence intensity in HUVEC compared with the $1.0 \mu \mathrm{mol} / \mathrm{L}$ Nif and $1.0 \mu \mathrm{mol} / \mathrm{L}$ Sim groups (Figure 6, between A, C, E, and G groups, without statistical difference, $P>0.05 ; P<0.05$ vs $\mathrm{B}$ group; $P<0.05$ vs $\mathrm{D}$, F group; $n=40-45$ cells), indicating that Nif+Sim enhanced the inhibition of ROS generation in HUVEC.

Impact of simvastatin and nifedipine on $\mathrm{Ca}^{2+}$ concentration changes in endothelial cells

Calcium ion is the most physiologically important second messenger in endothelial cells, and it serves as the primary medium for communicating information in the cells. Nifedipine is a calcium antagonist, but whether its protective effect on endothelial cells results from inhibiting $\mathrm{Ca}^{2+}$ increases remains unclear. We first stimulated HUVEC with 100 $\mu \mathrm{mol} / \mathrm{L} \mathrm{H}_{2} \mathrm{O}_{2}$, which induced increased intracellular $\mathrm{Ca}^{2+}$ concentration $\left(\left[\mathrm{Ca}^{2+}\right]_{\mathrm{i}}\right)$ in endothelial cells $(P>0.05, n=40-45$ cells, Figure 7). This effect on $\left[\mathrm{Ca}^{2+}\right]_{i}$ was significant after $10 \mathrm{~min}$ of stimulation and persisted up to $30 \mathrm{~min}$. Different concentrations of $\mathrm{Nif}(0.1,1.0$, and $10 \mu \mathrm{mol} / \mathrm{L})$ followed by the addition of $100 \mu \mathrm{mol} / \mathrm{L} \mathrm{H}_{2} \mathrm{O}_{2}$ also resulted in increased $\left[\mathrm{Ca}^{2+}\right]_{\mathrm{i}}$. There was no significant difference in $\left[\mathrm{Ca}^{2+}\right]_{\mathrm{i}}$ before and after Nif stimulation. Thus, $\mathrm{H}_{2} \mathrm{O}_{2}$-induced increases in $\left[\mathrm{Ca}^{2+}\right]_{\mathrm{i}}$ cannot be inhibited by Nif. This indicates that the protective effect of Nif on endothelial cells had no relation to the calcium signal. Further comparisons between combined $1.0 \mu \mathrm{mol} / \mathrm{L}$ Nif +1.0 $\mu \mathrm{mol} / \mathrm{L}$ Sim and the individual treatments of $1.0 \mu \mathrm{mol} / \mathrm{L}$ Nif and $1.0 \mu \mathrm{mol} / \mathrm{L}$ Sim also showed no significant difference in $\left[\mathrm{Ca}^{2+}\right]_{\mathrm{i}}$ stimulated by $100 \mu \mathrm{mol} / \mathrm{L} \mathrm{H}_{2} \mathrm{O}_{2}$. Therefore, the enhanced protective effect on endothelial cells by Sim did not occur via changes in intracellular calcium.

Combination treatment of nifedipine and simvastatin enhances Akt phosphorylation and the ratio of $\mathrm{p}$-eNOS/eNOS in endothelial cells

We wanted to investigate the mechanism by which increased eNOS regulates specific cellular functions. A previous report showed that ROS regulates the expression and activity of eNOS via the PI3K-Akt signaling pathway ${ }^{[16]}$. Akt activation led to activation of eNOS, increased eNOS phosphorylation (p-eNOS), and greater NO release. Here, we observed that, compared with the individual drug groups, combined Sim and Nif treatment up-regulated the level of Akt phosphorylation (without affecting total Akt) ( $P<0.05$ vs groups 2 and 3), enhanced p-eNOS ( $P<0.05$ vs groups 2 and 3 ) and total eNOS levels ( $P<0.05$ vs groups 2 and 3$)$, and increased the proportion of p-eNOS/eNOS ( $P<0.05$ vs groups 2 and 3$)$. These effects were inhibited by the PI3K inhibitors wortmannin and LY294002 ( $P<0.05$ vs groups 1,5 , and 6$)$. Taken together, these results indicate that combination treatment of Nif and Sim
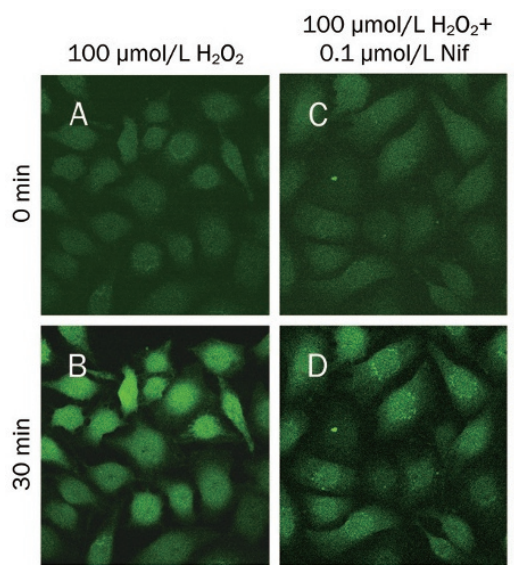
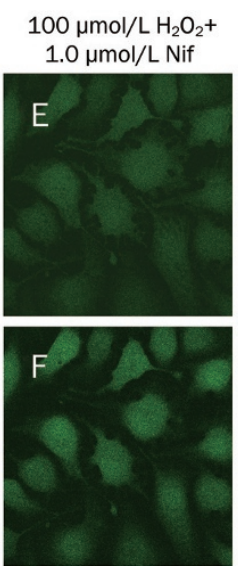

$100 \mu \mathrm{mol} / \mathrm{L} \mathrm{H}_{2} \mathrm{O}_{2}+$

$10 \mu \mathrm{mol} / \mathrm{L} \mathrm{Nif}$
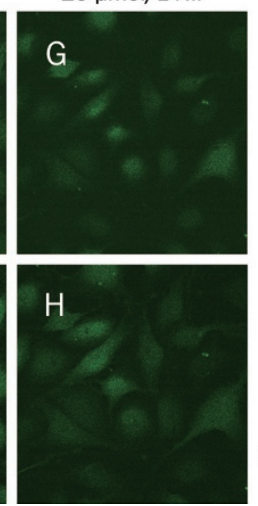
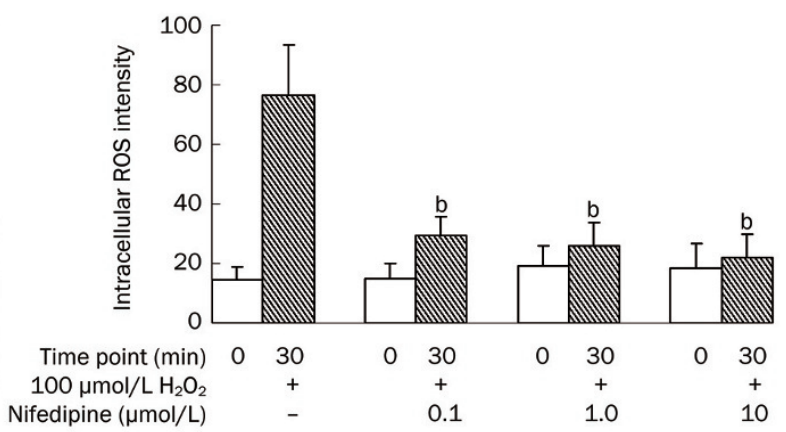

Figure 5. The concentration-dependent effect of nifedipine on ROS in endothelial cells after hydrogen peroxide-induced injury. Cells were pretreated with or without nifedipine $(0.1,1.0$, and $10.0 \mu \mathrm{mol} / \mathrm{L})$ and $100 \mu \mathrm{mol} / \mathrm{L} \mathrm{H}_{2} \mathrm{O}_{2}$ for $30 \mathrm{~min}$. Production of cellular ROS was determined by measuring the fluorescence intensity of the $\mathrm{CM}-\mathrm{H}_{2}$ DCFDA probe at $0 \mathrm{~min}$ and $30 \mathrm{~min}$. Cell brightness was measured using LaserPix Image software. Results are presented as mean \pm SEM for $35-45$ cells. Arbitrary units (au) represent fluorescent intensity corresponding to ROS changes. Groups at 0 min: no significant difference. ${ }^{\mathrm{b}} \mathrm{P}<0.05$ vs $100 \mu \mathrm{mol} / \mathrm{L} \mathrm{H}_{2} \mathrm{O}_{2}$ group at $30 \mathrm{~min}$. 

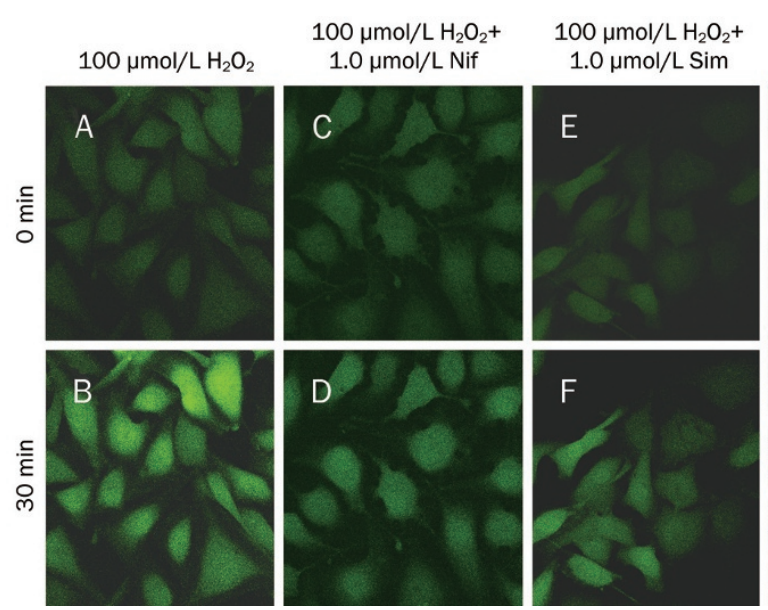

$1.0 \mu \mathrm{mol} / \mathrm{L} \mathrm{Nif+}$

$1.0 \mu \mathrm{mol} / \mathrm{L} \mathrm{Sim}$
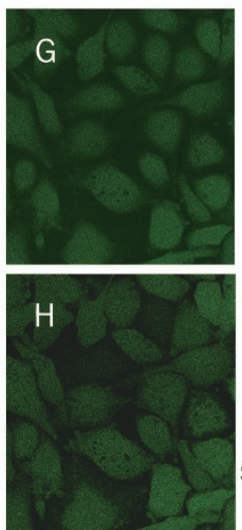

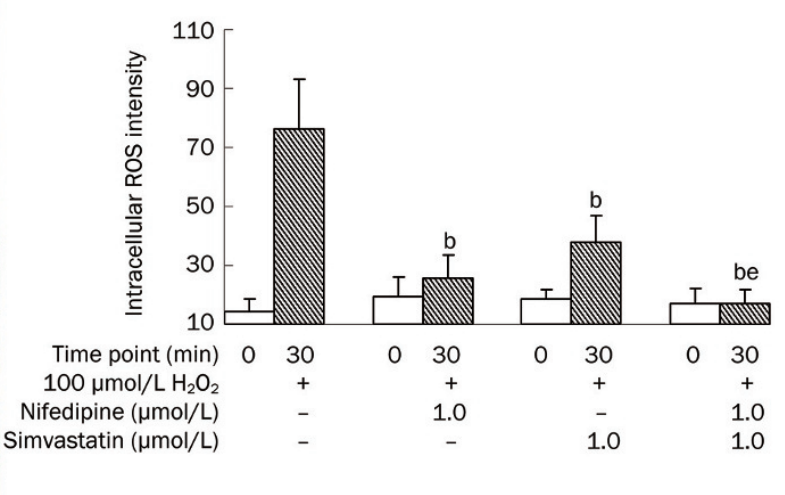

Figure 6. Effect of nifedipine combined with simvastatin on ROS in endothelial cells after hydrogen peroxide-induced injury. Cells were pretreated with $1.0 \mu \mathrm{mol} / \mathrm{L}$ nifedipine for $30 \mathrm{~min}$ or $1.0 \mu \mathrm{mol} / \mathrm{L}$ simvastatin for $2 \mathrm{~h}$ and $100 \mu \mathrm{mol} / \mathrm{L} \mathrm{H}_{2} \mathrm{O}_{2}$ for $30 \mathrm{~min}$. Production of cellular ROS was determined by measuring the fluorescence intensity of the $\mathrm{CM}-\mathrm{H}_{2}$ DCFDA probe at $0 \mathrm{~min}$ and $30 \mathrm{~min}$. Cell brightness was measured using LaserPix Image software. Results are presented as mean \pm SEM for $40-45$ cells. Arbitrary units (au) represent fluorescent intensity corresponding to ROS changes. Groups at 0 min: no significant difference. ${ }^{\mathrm{b}} \mathrm{P}<0.05$ vs $100 \mu \mathrm{mol} / \mathrm{L} \mathrm{H}_{2} \mathrm{O}_{2}$ group at $30 \mathrm{~min}$. ${ }^{\mathrm{e}} \mathrm{P}<0.05$ vs $100 \mu \mathrm{mol} / \mathrm{L} \mathrm{H}_{2} \mathrm{O}_{2}+1.0 \mu \mathrm{mol} / \mathrm{L} \mathrm{Nif}$ group or $100 \mu \mathrm{mol} / \mathrm{L}$ $\mathrm{H}_{2} \mathrm{O}_{2}+1.0 \mu \mathrm{mol} / \mathrm{L} \mathrm{Sim} \mathrm{group} \mathrm{at} 30 \mathrm{~min}$.

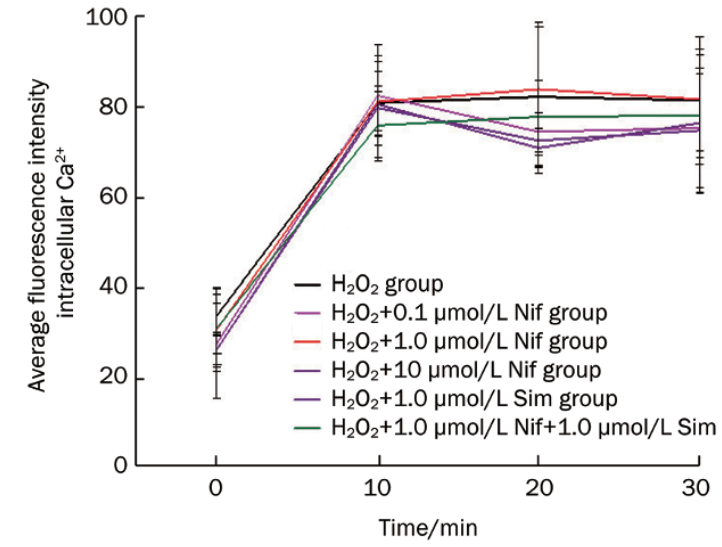

Figure 7. Effect of nifedipine combined with simvastatin on intracellular $\mathrm{Ca}^{2+}$ in endothelial cells after hydrogen peroxide-induced injury. The change in intracellular $\mathrm{Ca}^{2+}$ was determined by measuring the fluorescence intensity of the Fluo-3 probe. Cell brightness was analyzed by LaserPix Image software without enhancement. All experiments were performed with at least 40-45 cells. Arbitrary units (au) represent fluorescent intensity corresponding to intracellular $\mathrm{Ca}^{2+}$ changes. No significant difference. $P>0.05$.

enhances the activity of eNOS via regulation of Akt activity (phosphorylation), which is the basis for the protective role of Nif+Sim in endothelial cells (Figure 8).

\section{Discussion}

Endothelial cells are involved in many aspects of the generation and development of many cardiovascular maladies, such as hypertension and arteriosclerosis. Nitric oxide plays a role in stretching blood vessels, inhibiting the conglomeration of blood platelets and preventing conglutination between endothelial cells and between blood cells and endothelial cells. Nitric oxide plays a protective role in preventing the formation of hypertension and arteriosclerosis. Moreover, the expression of eNOS is the key factor for NO generation in endothelial cells. The synthesis and release of NO are markedly reduced in vascular endothelial cells of hypertension patients. Therefore, regulating eNOS expression and enhancing NO secretion will be important methods of reducing hypertension and preventing and controling arteriosclerosis ${ }^{[17-19]}$.

A typical model of endothelial cell damage is $\mathrm{H}_{2} \mathrm{O}_{2}$-induced damage. The use of this model helps in the study of the pathogenesis of cardiovascular diseases and in screens for drugs that protect blood vessels. The present investigations of eNOS mRNA and protein levels demonstrated that Nif enhances the expression of eNOS in endothelial cells and participates in the protection of endothelial cells. The expression of eNOS was also up-regulated by treatment with Sim alone. Moreover, we showed that the protective effect on endothelial cells was enhanced by combination treatment of Sim and Nif compared with either drug treatment separately. As shown here and previously ${ }^{[20,21]}, 1.0 \mu \mathrm{mol} / \mathrm{L}$ Nif and $1.0 \mu \mathrm{mol} / \mathrm{L}$ Sim are not cytotoxic to endothelial cells; on the contrary, they have a protective effect on endothelium.

For the regulatory mechanism of eNOS expression, it has been reported that an increased ROS level in endothelial cells inhibits the expression of $\operatorname{eNOS}^{[22,23]}$, which is one of the reasons for hypertension in elderly people. The results of our study show that stimulation of endothelial cells with $\mathrm{H}_{2} \mathrm{O}_{2}$ can enhance the ROS level in endothelial cells. Nifedipine inhibited this ROS generation in a dose-dependent manner. The fluorescence intensity was further reduced in the cells with the combination treatment of Sim and Nif, which was concomitant with increased eNOS expression and NO level. This indicates 

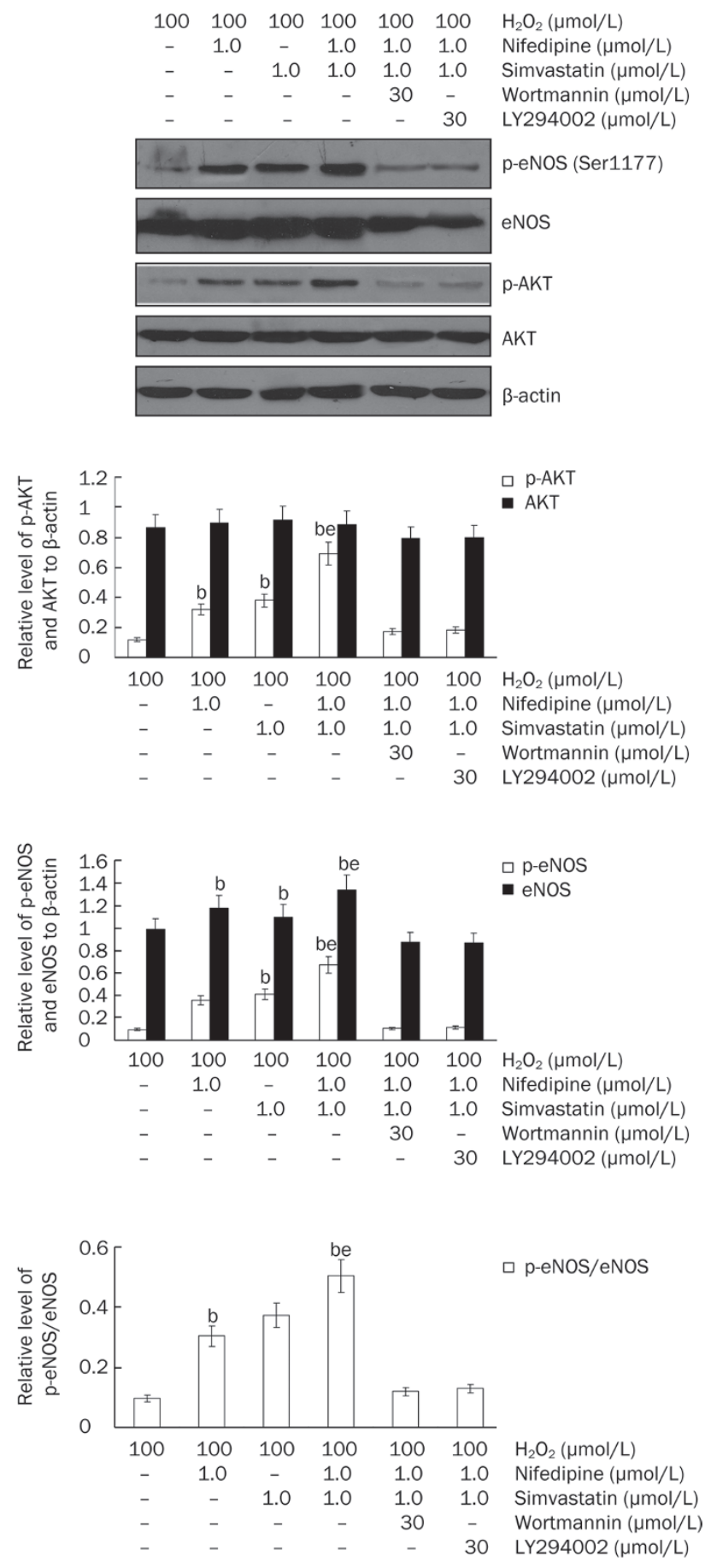

Figure 8. Effect of simvastatin combined with nifedipine on p-eNOS/ eNOS and $\mathrm{p}-\mathrm{AKT} / \mathrm{AKT}$ expression in endothelial cells after hydrogen peroxide-induced injury. Optical densities of eNOS, p-eNOS, p-AKT, and AKT were obtained after normalization to $\beta$-actin. Data are presented as mean \pm SEM from three independent experiments. ${ }^{b} \mathrm{P}<0.05 \mathrm{vs}_{2} \mathrm{O}_{2}$ alone group, $\mathrm{H}_{2} \mathrm{O}_{2}+\mathrm{Nif}+\mathrm{Sim}+$ Wortmannin group, and $\mathrm{H}_{2} \mathrm{O}_{2}+\mathrm{Nif}+\mathrm{Sim}+\mathrm{LY} 294002$ group. ${ }^{e} \mathrm{P}<0.05$ vs $\mathrm{H}_{2} \mathrm{O}_{2}+\mathrm{Nif}$ or $\mathrm{H}_{2} \mathrm{O}_{2}+\mathrm{Sim}$ group.

that Sim combined with Nif enhances eNOS expression and NO secretion by inhibiting intracellular ROS generation.
Although Nif serves as an inhibitor of cell membrane L-type calcium channel, it is still disputed whether it protects endothelial cells via inhibiting extracellular calcium ion influx. It has been reported that increased intracellular $\mathrm{Ca}^{2+}$ may inhibit the expression of eNOS. Therefore, we asked whether the combination treatment of Nif and Sim could also enhance eNOS expression by inhibiting intracellular $\mathrm{Ca}^{2+}$ changes. We found no visible $\mathrm{Ca}^{2+}$ changes in HUVEC after stimulation with $\mathrm{H}_{2} \mathrm{O}_{2}$ with or without Nif and/or Sim. This indicates that enhanced eNOS expression by Nif and Sim was not a result of the inhibition of calcium influx, in agreement with the results of Aono et $a l^{[24]}$. A recent study indicated that L-type $\mathrm{Ca}^{2+}$ channels did not exist in the endothelial cell membrane ${ }^{[25]}$. It was reported in other studies ${ }^{[26]}$ that Nif combines with cell membrane lipids directly to inhibit ROS production, due to the specificity of its molecular structure. Moreover, endothelial cells stimulated with $\mathrm{H}_{2} \mathrm{O}_{2}$ may induce a series of biological effects via the release of endoplasmic reticulum $\mathrm{Ca}^{2+}$ to increase $\mathrm{Ca}^{2+}$ concentration in the cytoplasm ${ }^{[27]}$. Here, Nif was unable to block the increase of influx of extracellular $\mathrm{Ca}^{2+}$ into the cells. Therefore, this result is not in contradiction with Nif serving as an antagonist of the calcium signaling pathway. Nif protects endothelial cells by directly inhibiting ROS generation.

PI3K/Akt signaling regulates the activity of eNOS and enhances NO release from endothelial cells ${ }^{[28]}$. The excessive production of ROS damages the cells, but lower concentrations of ROS are able to activate the PI3K/Akt/eNOS pathway and enhance the activity of eNOS (raise the level of eNOS phosphorylation), thereby protecting the endothelial cells. The results of this study also support this conclusion, as the combination treatment of Nif and Sim reduced ROS levels, up-regulated Akt phosphorylation relative to total Akt, enhanced the levels of both phosphorylated and total eNOS, and raised the proportion of p-eNOS/eNOS. This effect was more significant from the combination treatment than from each drug separately. Our results are consistent with a mechanism in which Nif combines with cell membrane lipids directly to resist ROS over-production. Yamagishi et al ${ }^{[29,30]}$. demonstrated that Nif directly abrogates vascular reduced nicotinamide-adenine dinucleotide phosphate (NADPH) oxidase activity in endothelial cells. Furthermore, Sim inhibits $\mathrm{ROS}\left(\mathrm{O}_{2}^{-}, \mathrm{OH}^{-}\right)$production, possibly by decreasing NADPH oxidase and increasing peroxiredoxin 3 / thioredoxin 2 antioxidant activities ${ }^{[31]}$.

In summary, we discovered that combination treatment of Sim and Nif enhanced the expression of eNOS mRNA and protein, up-regulated the ratio of $\mathrm{p}$-eNOS/eNOS, increased NO secretion and enhanced the protective effect of the two drugs individually on endothelial cells. The combination treatment works by reducing the generation of ROS in the cells and up-regulating Akt activation, rather than via inhibition of calcium signaling. These results provide the basis for their use in clinical practice, and they indicate that Sim combined with Nif will be useful in reducing hypertension and preventing/ treating arteriosclerosis. 


\section{Author contribution}

Zhuo YANG and Ming FAN designed the research; Xiaoniao CHEN performed the experiments; Zhe FENG and Jingyao HAN contributed new reagents or analytic tools; Jun XU analyzed data; Xiao-niao CHEN and Zhuo YANG wrote the paper.

\section{References}

1 Jiang JY, Wong MC, Zhang XH, Fung H, Griffiths S, Mercer S. Profiles of mortality among Chinese hypertensive patients in Hong Kong: a cohort study. J Hum Hypertens 2009; 23: 735-42.

2 Matthys $\mathrm{KE}$, Bult $\mathrm{H}$. Nitric oxide function in atherosclerosis. Mediators Inflamm 1997; 6: 3-21.

3 Ross R. The pathogenesis of atherosclerosis: a perspective for the 1990s. Nature 1993; 362: 801-9.

4 Noll G, Tschudi M, Nava E, Luscher TF. Endothelium and high blood pressure. Int J Microcirc Clin Exp 1997; 17: 273-9.

5 Moncada S, Palmer RM, Higgs EA. Nitric oxide: physiology, pathophysiology, and pharmacology. Pharmacol Rev 1991; 43: 109-42.

6 Rabelink TJ, Luscher TF. Endothelial nitric oxide synthase: host defense enzyme of the endothelium? Arterioscler Thromb Vasc Biol 2006; 26: 267-71.

7 Zanchetti A. The antiatherogenic effects of antihypertensive drugs: experimental and clinical evidence. Clin Exp Hypertens A 1992; 14: 307-31.

8 Lichtlen PR, Hugenholtz PG, Rafflenbeul W, Hecker H, Jost S, Deckers JW. Retardation of angiographic progression of coronary artery disease by nifedipine. Results of the International Nifedipine Trial on Antiatherosclerotic Therapy (INTACT). INTACT Group Investigators. Lancet 1990; 335: 1109-13.

9 Matsubara M, Hasegawa K. Benidipine, a dihydropyridine-calcium channel blocker, prevents lysophosphatidylcholine-induced injury and reactive oxygen species production in human aortic endothelial cells. Atherosclerosis 2005; 178: 57-66.

10 Deng HF, Xiong Y. Effect of pravastatin on impaired endotheliumdependent relaxation induced by lysophosphatidylcholine in rat aorta. Acta Pharmacol Sin 2005; 26: 92-8.

11 Ma FX, Liu LY, Xiong XM. Protective effects of lovastatin on vascular endothelium injured by low density lipoprotein. Acta Pharmacol Sin 2003; 24: 1027-32.

12 Gerson RJ, MacDonald JS, Alberts AW, Kornbrust DJ, Majka JA, Stubbs $\mathrm{RJ}$, et al. Animal safety and toxicology of simvastatin and related hydroxy-methylglutaryl-coenzyme A reductase inhibitors. Am J Med 1989; 87: 28S-38S.

13 Todd PA, Goa KL. Simvastatin. A review of its pharmacological properties and therapeutic potential in hypercholesterolaemia. Drugs 1990; 40: 583-607.

14 Ye G, Metreveli NS, Ren J, Epstein PN. Metallothionein prevents diabetes-induced deficits in cardiomyocytes by inhibiting reactive oxygen species production. Diabetes 2003; 52: 777-83.

15 Brunt KR, Fenrich KK, Kiani G, Tse MY, Pang SC, Ward CA, et al. Protection of human vascular smooth muscle cells from $\mathrm{H}_{2} \mathrm{O}_{2}$-induced apoptosis through functional codependence between HO-1 and AKT. Arterioscler Thromb Vasc Biol 2006; 26: 2027-34.

16 Koneru S, Penumathsa SV, Thirunavukkarasu M, Samuel SM, Zhan L, Han Z, et al. Redox regulation of ischemic preconditioning is mediated by the differential activation of caveolins and their association with eNOS and GLUT-4. Am J Physiol Heart Circ Physiol 2007; 292: H2060-72.

17 Ignarro LJ, Buga GM, Wood KS, Byrns RE, Chaudhuri G. Endotheliumderived relaxing factor produced and released from artery and vein is nitric oxide. Proc Natl Acad Sci USA 1987; 84: 9265-9.

18 Huang PL, Huang Z, Mashimo H, Bloch KD, Moskowitz MA, Bevan $\mathrm{JA}$, et al. Hypertension in mice lacking the gene for endothelial nitric oxide synthase. Nature 1995; 377: 239-42.

19 Hyndman ME, Parsons HG, Verma S, Bridge PJ, Edworthy S, Jones C, et al. The T-786 $\rightarrow$ C mutation in endothelial nitric oxide synthase is associated with hypertension. Hypertension 2002; 39: 919-22.

20 Mak IT, Boehme P, Weglicki WB. Protective effects of calcium channel blockers against free radical-impaired endothelial cell proliferation. Biochem Pharmacol 1995; 50: 1531-4.

21 Henrich D, Seebach C, Wilhelm K, Marzi I. High dosage of simvastatin reduces TNF-alpha-induced apoptosis of endothelial progenitor cells but fails to prevent apoptosis induced by IL-1beta in vitro. J Surg Res 2007; 142: 13-9.

22 Ungvari Z, Csiszar A, Kaley G. Vascular inflammation in aging. Herz 2004; 29: 733-40

23 Hansson GK. Inflammation, atherosclerosis, and coronary artery disease. N Engl J Med 2005; 352: 1685-95.

24 Aono Y, Ariyoshi H, Sakon M, Ueda A, Tsuji Y, Kawasaki T, et al. Human umbilical vein endothelial cells (HUVECs) show $\mathrm{Ca}^{2+}$ mobilization as well as $\mathrm{Ca}^{2+}$ influx upon hypoxia. J Cell Biochem 2000; 78: 458-64.

25 Himmel HM, Whorton AR, Strauss HC. Intracellular calcium, currents, and stimulus-response coupling in endothelial cells. Hypertension 1993; 21: 112-27.

26 Cominacini L, Fratta Pasini A, Garbin U, Pastorino AM, Davoli A, Nava $\mathrm{C}$, et al. Antioxidant activity of different dihydropyridines. Biochem Biophys Res Commun 2003; 302: 679-84.

27 Mason RP, Trumbore MW. Differential membrane interactions of calcium channel blockers. Implications for antioxidant activity. Biochem Pharmacol 1996; 51: 653-60.

28 Lenasi H, Kohlstedt K, Fichtlscherer B, Mulsch A, Busse R, Fleming I. Amlodipine activates the endothelial nitric oxide synthase by altering phosphorylation on Ser1177 and Thr495. Cardiovasc Res 2003; 59: 844-53.

29 Yamagishi S, Nakamura K, Takenaka K, Matsui T, Inoue H. Pleiotropic effects of nifedipine on atherosclerosis. Curr Pharm Des 2006; 12: 1543-7.

30 Yamagishi S, Nakamura K, Matsui T. Role of oxidative stress in the development of vascular injury and its therapeutic intervention by nifedipine. Curr Med Chem 2008; 15: 172-7.

31 Thomas SR, Witting PK, Drummond GR. Redox control of endothelial function and dysfunction: molecular mechanisms and therapeutic opportunities. Antioxid Redox Signal 2008; 10: 1713-65. 